\title{
The Benefits of Cloud Computing for Children with Special Educational Needs in Education or Using Cloud Computing as Assistive Technology
}

\author{
Vania Angelova Sivakova \\ University of Plovdiv "Paisii Hilendarski" \\ Faculty of Pedagogics \\ Department of "Pedagogics and education management" \\ "Tzar Assen" str. 24, Plovdiv 4000, Bulgaria
}

\begin{abstract}
The paper reveals the benefits of cloud-based education technologies and the possibility of using them in inclusive education for equal access to it. Basic concepts related to cloud technologies are discussed. Some strategies for the use of cloud technologies in children and pupils with special educational needs as assistive technologies are mentioned.
\end{abstract}

Keywords: Cloud technology, assistive technology, inclusive education, special educational needs.

\section{Introduction}

Education is an important part of every person's life. The knowledge a man has acquired over the years gives confidence, certainty and assurance in a future success. It gives an opportunity to find an appropriate social status and professional realization. In our contemporary society, education is based on the principle of equal access and inclusion of every child and pupil. Inclusive education (IE) applies to all children, but the most vulnerable group are children and pupils with special educational needs (SEN). Modern tendencies in applying the principles of inclusive education provide new opportunities for inclusion of all pupils in the education process.

Information and computer technologies (ICT) play an important role in the life of modern person and his education. Learning already includes mobile devices (tablets, smartphones). In some countries, paper textbooks have already been replaced by electronic ones, and students have tablets instead. E-learning is also being developed and web-based training is intensively used today. Cloud technologies are becoming more and more popular.

The use of a computer in education gives an opportunity to organize better the education in schools as well as the ways and methods of presenting the verbal and visual material. It gives an opportunity to support the individual development of each child and pupil, to include them, and to form more complex thinking processes, and thus enabling more advanced pupils to reach a high level of cognitive development.

For effective inclusion of children in the general education environment there has been described several good practices. The implementation of inclusion in practice raises many questions. Several factors influence this process, such as accessibility of the environment, parental awareness, teacher training and non-teaching staff, etc. One of the necessary competences of an inclusive teacher is that he must be able to encourage the academic learning of all pupils as well as to stimulate collaboration work as a learning approach and to meet the various needs of pupils (Watkins, 2012). This is a challenge for him, as all students are different, with different styles of learning and needs. An even greater challenge is the inclusion of children and students with SEN. The reasons for this are many, the lack of knowledge of SENs by teachers, the negative attitudes of society (other pupils, parents and teachers themselves), etc.

Assistive technologies facilitate the inclusion and interactive participation of children and students in kindergartens and schools. Assistive technologies (AT) supports some of the main goals of inclusive education, namely: a sense of belonging to a group, joint activities with other children and pupils and a balanced educational experience. AT help children and students in their daily life and educational functioning.

Assistive Technology (AT) plays an important role in the lives of children with special educational needs. They increase their independence and participation in learning by giving them an opportunity to develop, learn and play with their coevals, through different technical solutions. ATs enable many of them to communicate and interact with their classmates, teachers and parents, which otherwise may be impossible. ATs increase the frequency of completion of tasks and contribute to improving motivation for learning. ATs can facilitate access to schools by helping children with SEN overcome the challenges of movement, writing, reading, math problems, problem solving, and communication, both at school and at home. 
Assistive technologies have great applicability not only for children with SEN but for all children and students. They can, for example, to help children with prominent talents to develop their skills in different areas.

The purpose of this paper is to reveal the benefits of cloud technologies for education and the possibility to use them as assistive technologies for equal access to education.

\section{Cloud and Cloud Computing}

Cloud is a term that refers to the Internet or a computer network (as shown in the chart of computer networks to present the complex infrastructure it presents) (Mell, 2011). In other words, we can say that the cloud is something that is in a remote place. The cloud can provide services over a network. Software application such as e-mail, web conferencing, all are running in a cloud. Cloud computing is a term in the field of information technology that has recently gained popularity and will become even more popular in the field of education. Cloud computing is an Internet based calculation. The idea of a cloud computing is not recent. Cloud computing is believed to have been invented by Joseph Licklider in the 1960s with his work on ARPANET to connect people and data from anywhere at any time ${ }^{1}$.

There are many different definitions for cloud computing and new ones are constantly appearing. The US National Institute for Standards and Technology gives the following definition of cloud computing: a model for enabling ubiquitous and convenient on-demand network access to a shared pool of configurable computing resources (networks, servers, storage, applications, and services) that can be rapidly provided and releasedwith minimal managementefforts or service provider interaction. This cloud model is composed of five essential characteristics, three service models, and four deployment models (Mell, 2011).

Cloud services include: data storage, cloud office applications (documents, presentations, spreadsheets, forms, etc.) and infrastructure (Cloud Computing tutorial, 2019). Cloud computing is a new service-based approach. In other words, the concept refers to both software applications provided in the form of web services and the access to the hardware and system resources of the data center that offers these services. Cloud provides services, not a product. Cloud computing is a model for using shared resources stored on a remote server instead of a local disk space.

Users have permanent access to cloud services from anywhere, anytime, and any device that has Internet access. Cloudy technologies provide a flexible learning environment abundant in opportunities, resources and tools.

Cloudy technologies in education have economic benefits. They help to reduce the cost of hardware, software and IT professionals. Cloud technology may not require the purchase of hardware or software to use it. Cloud technologies offer free services, but some services are paid. Virtualization and other capability of cloud computing systems facilitate service delivery at a lower cost than traditional infrastructures. Cloud computing allows schools to increase efficiency and achieve greater economies of scale. Organizations can reduce or eliminate IT capital expenditures and decrease ongoing operating expenses by paying only for the services they use and potentially by reducing or redeploying IT staff (Bouyer, 2014).There is no need to pay IT specialists to support software and hardware (Jordanova, 2016).

Another important benefit for education (Bouyer, 2014) are:

Delivery of various services is quickly. Cloud computing enables lecturers/teachers to quickly arrange educational services that enhance learning and enable teachers to individualize learning based on performance data and each student's unique learning style. Cloud-based administrative applications can standardize processes, provide access to centralized information stores, and increase reporting consistency.

Reduce risk and enhance security: cloud security helps district IT staff reduce risk, which enables consistent security policies and enforcement, up-to-date threat intelligence, high scalability, and improved performance. For example, Cisco cloud security helps remove barriers to cloud computing so that schools can achieve the educational and business benefits of the cloud-computing platform.

Reshape teaching and expand collaboration: cloud-based educational system offers a portfolio of cloud services that can extend a rich interactive learning environment to anyone, anywhere. These cloud services can also simplify administrative processes and cost-effectively train faculty and staff across geographical boundaries.

Access to cloud technologies is available from any mobile device or computer without high requirements for device parameters. This way old technology can be utilized and users with older phones and tablets will also be able to use cloud technologies. There are also free cloud services, of course, with a limitation of the cloud space that is being used. But it is almost enough for an ordinary user. In addition, cloud service providers are deploying new IT solutions without the need for users to buy the new version and / or replace hardware to use the new software.

\footnotetext{
${ }^{1}$ Cloud storage,https://en.wikipedia.org/wiki/Cloud_storage
} 
This ensures compatibility of the files of different users. Users can increase or decrease at any time the amount of resources they need without interacting with a service provider's representative. They pay the actual consumption i.e. the resources they used. All users use the same versions of software cloud applications. They do not have to comply with other users who will use their files (documents, tables, presentations) (Murah, 2012).

Other advantages of cloud technologies are related to efficiency, flexibility and accessibility.

Some of the main features of cloud technologies are the ability to collaborate between all participants in the learning process (using cloud technologies) and the sharing of learning resources and activities. There is no need to record data on a media and deliver it so that other users can get the information they need. This includes also attaching files to emails and exchanging different versions of files. Cloud technologies save a lot of time and the teacher / lecturer can focus on specific activities. This stimulates and supports the research work of the teacher / lecturer.

Cloud technologies also have some disadvantages. They mostly concern data protection that is more vulnerable to the cloud than it is on a personal computer. Another disadvantage is that the service provider may at any time discontinue its provision.

Cloud office applications, in addition to allowing document creation and editing, provide the ability to communicate via chat and comments in the documents themselves. They include calendars and contact management tools and storage for the files being worked on. Examples of cloud office applications are Amazon WorkDocs, Google Docs, Microsoft Office 365, Zoho, and more. Cloud office applications are SaaS (Software as a Service) (Andreeva, 2017). There are, of course, packages designed for business users with additional services such as personal email business mail support, unlimited cloud space and more. Cloud offers data storage as well as data synchronization between different devices and users, if the cloud application offering this service is installed. Examples of data storage in Cloud are DropBox, Google Drive, Microsoft OneDrive, and others. Specific educational applications are eLearning environments and cloud classroom such as Microsoft OneNote, Google Classroom and Microsoft Sway. There are also many other cloud communication applications (like Hangouts), calendars, social networks, and more.

\section{Assistive Technologies}

There are many definitions of assistive technology. AT were first defined in federal law in the Individuals with Disabilities Education Act of 1990 (IDEA). Assistive technology refers to "any item, piece of equipment, or product system, whether acquired commercially, modified, or customized, that is used to increase, maintain, or improve functional capabilities of individuals with disabilities". AT is defined and by World Health Organization as "any means or content that allows individuals to perform tasks that cannot be self-fulfilling or facilitating the way and security of performance of the activity" (Jankova, 2016).

AT are classified as low-tech and high-tech. In some classifications there is a medium-tech category. Low-tech ATs are aids - mechanical devices, part of equipment or device. High-tech ATs can be sophisticated electronic devices, electromechanical operations devices, information technology, software and hardware (Wilson, 2017), portable devices such as tablets and mobile phones, adaptive technologies.

AT are classified in the following categories (Wilson, 2017; Reed, 2017):

- seating, positioning and mobility

- activities for daily living;

- recreation and leisure;

- writing;

- reading;

- organization;

- mathematics;

- communication;

- computer access;

- low hearing or deafness;

- low vision or blindness;

- multiple challenges;

- architecture and universal/ inclusive design.

Another classification of AT is according to SEN categories. The concept 'special educational needs' is defined in the Pre-school and School Education Act in Bulgaria. SENs may arise in: sensory impairments, physical disabilities, multiple impairments, intellectual disabilities, language disorders, specific learning disabilities, autistic spectrum disorders, emotional and behavioral disorders (LPSE, 2017). 


\section{Cloud Technologies As Assistive}

Cloud technologies can be particularly useful in inclusion children and students with SEN in education. They can be used as an AT. Except for children and students with SEN cloud technologies, can also be used effectively for other students.

An inclusive teacher should be able to stimulate student collaboration (Watkins, 2012). In this case, cloud technologies are a very appropriate tool. The teacher can prepare a task or project for a group of students. For example, developing a common presentation on a given subject. All who are working on the project will see the presentation and what the others are working on in the same time, can leave comments and chat in real time. There is no need for the students to wait each other to make their part of the presentation and attach it to email to the next one.

A core value related to teaching and learning, identified as a basis for the work of all teachers in the inclusive education, is the ability to value the student diversity (student difference is considered as a resource and an asset to education). The teacher must use different strategies to work with the different student to support them (Watkins, 2012).

Some students work slower than others or need support for learning. In this case, the teacher can use a cloud classroom and provide additional didactic materials. Parents can also access the provided materials and assist their children in training.

Children and students with physical disabilities have limitations or inability to carry out basic movements or even experience significant difficulties in attending school. Physical disabilities can determine specificity in sensory, physical, intellectual and social-emotional development. They can impede training and require special education (Levterova, 2018).

Assistive technologies in this case are particularly applicable and even mandatory. It is effective to use eye-control systems as they allow access to the Internet and multiple applications, and these for communication. The eye-controlled systems enable children and students with severe physical disabilities who cannot communicate and cannot move their hands to use a computer. Special cameras monitor the child's eyesight in real time. The eye is used to control a computer mouse, i.e. the eye moves the mouse over the screen. All software applications are available on one computer with the help of this system. These systems are becoming more and more accessible to consumers. They can be used along with a cloud classroom in which the teacher can provide didactic material to a physically disabled student and thus have access to lessons and education.

Students with hearing impairments (hard hearing) are unable to perceive all the sound signals and rely on their vision to perceive the information. Communication is primarily visual, reading, lip reading and sign language (Obukowicz, 2015). Working in class for them may be difficult because they have to follow the teacher's face to perceive the information through their vision and at the same time take notes. Cloud classroom can provide a quiet environment in which these students to read the material, to provide important messages that will surely reach them.

Most children use their vision as the main source of information perception, not only for reading and writing, but also in social contacts and their day-to-day activities. Visual impairments or low vision may put the student in an unequal position. It is important to think about these students when creating teaching materials and tools and presenting them. Using cloud technologies can:

- help eliminate additional sources of sounds and noises in a classroom using a cloud classroom;

- use reading software for presentations and other materials;

- provide materials for a forthcoming topic like a shared file or task in a cloud classroom;

- format the text in the materials provided, the more important paragraphs can be marked in different colors, with a bigger font;

- provide an audio recording of a lesson.

A very good option is for the pupil to receive the materials in an electronic version. Testing, practical work and tests can be provided with cloudy applications.

Specific learning disabilities (SLDs) are manifested in different ways. Some of the behavioral characteristics of the SEMC are demonstrated as (Reed, 2017):

- difficulties in organizing the activity and bringing to completion the relevant task, organizing the information and materials in the education;

- general clumsiness - clumsy movements, indiscriminately and improper use of both hands;

- the necessity for more time to complete the task;

- difficulties in organizing learning and other aspects of life

- frequent repetitions of different kinds of action; 
- some children are hyperactive and may have impulsive behavior, and other hypoactive with slow and slow movements;

- difficulties in acquiring new skills to the degree of automation, such as reading and writing,

- difficulties of an academic nature. The most common are the difficulties in the process of reading, writing, mathematical operations and creative activities (visual, musical).

The children with SLDs also have difficulty in linguistic competence - misinterpret words, misunderstand the meaning of text, etc.

Other common characteristics are: a low sense of time, confusion of dates, hours and engagements; poor fine motor movements - e.g. hardly controls the pen and writes with ugly handwriting and many scratches; poor short-term memory - difficult to remember instructions, difficult to transcribe from a board and remember what has been said / read just now; difficulty in choosing words and misinterpreting words; difficulties in the visual storage of words, signs, symbols and formulas; difficulties in understanding, although reading may be smooth; problems with the sequence of instructions or mathematical tasks, difficulties in using dictionaries, encyclopedias and folders; brief holding of attention and low concentration.

The organization is a complex process involving many components such as self-organization, information management, time management, and materials management in learning. Organizational skills are needed to function in a school environment. Even when starting school, students are expected to follow instructions related to the learning process organization, to follow a daily schedule for hours and breaks and etc. ${ }^{2}$

Lack of organization can be a barrier to day-to-day tasks and homework, as well as success in the education process. Students are expected to acquire, store, and use information at school. Managing information can be challenging. ATs can help manage, sort information to facilitate communication and understanding. A good strategy for managing information and time is to analyze the tasks, i.e. break the tasks into smaller ones and determine the time needed for the separate activities.

The stress additionally intensifies these disabilities and is very embarrassing for both student with the SLDs and the teacher, and over time prevents the student from performing well.

The realization of some of the common strategies in working with students with SLDs, can be implemented with cloud technologies, in particular a cloud classroom. Cloud technology features such as collaboration and resource sharing are a tool for achieving some of the strategies such as:

- To avoid discussing the student's difficulties in front of the rest of the class. Instead of providing additional material to the student in front of the other students, the teacher can do this by sharing in cloud. The confidentiality is achieved with cloud technology. Many students feel inconvenience by the fact that the teacher has a special attitude towards them. Cloud classrooms provide the opportunity to provide an assignment that is designed for a student without others being aware of it.

- To use additional ways to visualize information such as presentations, charts, graphs, maps, etc. Presentations can be prepared with a cloud presentation application and shared with the student in a cloud or added as a cloud classroom assignment. The student does not need to install anything on your device.

- Provide compact and summarized information or lessons in oral or written form (where possible), to make a structured lesson plan. Providing them in the Cloud is an advantage over a paper version. This will ensure easy, fast, and constant access to information from any device with Internet.

- To make a dictionary with new and difficult words for the student. They can be shared with him in the Cloud. He will have permanent access to them and will find them faster than if they were provided on paper.

There is a font called Adys, created by Kristina Kostova, developed specifically on the Bulgarian alphabet and has several features that increase the readability of the text. This font was created specifically for people with dyslexia and is available for free download and using on a computer (Obukowicz, 2009). The teacher can use it to create the student's material with the SDLs and to achieve greater readability of the materials provided to him.

Cloud application Calendar can greatly facilitate students with SLDs with difficulty in information and materials organization. The teacher can set up reminders for tests, school materials, reminders of important events, etc.

Creating cloud application forms does release the teacher to check the result as the test is automatically evaluated. This leaves him more time for the more important things to develop and enrich his knowledge and skills.

${ }^{2}$ Jankova, V. Special font-style for people with dyslexia. (in Bulgarian)[Янкова В. Специален шрифт за хора с дислексия, https://dariknews.bg/novini/obshtestvo/mlada-bylgarka-syzdade-specialen-shrift-za-hora-s-disleksiia-2005894]

152 
The use of cloud technologies in education will also enable parents to become more active participants in the learning process of their children. For example, giving an assignment in a cloud classroom, where parents have access, will engage them in helping their child at home.The parent can access the shared didactic materials and be informed what his child is studying, and to support his child training at home.

\section{Conclusion}

Inclusion is a complex process of planning, organization, selecting and conducting specific activities. In inclusive classroom we can meet children with different characters and degree of disorder and/or health problems that have an impact on the overall development. The basis of the development of all children is the good knowledge of the child's personality, its abilities and needs, and the methods for his supporting.The leading role in this process has an inclusive teacher and his competencies related to his new educational role. Inclusion to the education process and the education of children and pupils is a dynamic process that requires continuous professional development, improving qualification, knowledge of the novelties in the field of education.

Cloudy technologies are rapidly coming in education. This places teacher in front of new challenges, to acquire new skills to work with new ICTs and uses them in his practice. Cloud technologies are quite attractive with their many benefits to education. They have already entered schools. They allow virtual space to be used for publishing materials, searching for teacher feedback from students, to assign individual tasks, and all that is done in parallel. Cloud Technology allows the teacher to support all students (including SEN students) by providing them assignments and didactic materials according to their unique needs.

Cloud technologies can also be used for practical training in many disciplinessuch as: Information Technology, Cloud Technology, Foreign Language, etc.

\section{Literature}

Andreeva, M. (2017). Cloud technologies - application in electronic education. PROCEEDINGS OF UNIVERSITY OF RUSE - 2017, volume 56, book 11. FRI-216-1-NSMTS(S)-02. http://conf.uni-ruse.bg/bg/docs/cp17/11/1110.pdf (in Bulgarian) [Андреева, M. (2017). Облачнитетехнологии - приложение в електроннотообучение. PROCEEDINGS OF UNIVERSITY OF RUSE - 2017, volume 56, book 11. FRI216-1-NSMTS(S)-02. http://conf.uni-ruse.bg/bg/docs/cp17/11/11-10.pdf].

Bouyer, As., B.Arasteh (2014). The necessity of using cloud computing in educational system. Procedia - Social and Behavioral Sciences. pp. 581-585. 143 ( 2014 ) 581 - 585, doi: 10.1016/j.sbspro.2014.07.440

Cloud computing tutorial (2019), https://www.tutorialspoint.com/cloud_computing/cloud_computing_tutorial.pdf

Jankova, J. (2016). Assistive technologies for education of children and students with special educational needs. University of Plovdiv "PaisiiHilendarski". Plovdiv. Dissertation for awarding the scientific degree "doctor of science" http://procedures.uni-plovdiv.bg/docs/procedure/875/4140553111199757174.pdf (in Bulgarian)

[Янкова, Ж. (2016). Помощнисредства и технологиизаобучениенадеца и

ученицисъсспециалниобразователнипотребности в професионалнатаподготовканаресурснитеучители.

Авторефератзаприсъжданенанаучнатастепен ,докторнанауките“, ПУ „П. Хилендарски“, Пловдив. http://procedures.uni-plovdiv.bg/docs/procedure/875/4140553111199757174.pdf].

Jordanova, L. \&Kiryakova G. (2016). Cloud technologies in education. http://www.dipkusz.net/sites/default/files/dannytk/16_forum_lina_iordanova.pdf

Levterova, D., Atanasova, J., Trichkov, Iv., Kostova, Zl. \&Sivakova, V. (2018). Psychology of children and students with special educational needs. University Publisher "PaisiiHilendarski". Plovdiv. ISBN 978-619-202-310-2. (in Bulgarian) [Левтерова, Д., Атанасова, Ж., Тричков, Ив., Костова, Зл., Сивакова, В. (2018). Психология на деца и ученици със специални образователни потребности. Университетско издателство „Паисий Хилендарски“. ISBN 978-619-202-310-2].

LPSE. Law of preschool and school education. (2017). (in Bulgarian) [Законзапредучилищно и училищнообразование. (2017)].

Mell, P. \&Grance, T. (2011). The NIST definition of cloud computing, Recommendations of the National Institute of Standards and Technology. Special Publication 800-145. September 2011. https://www.profsandhu.com/cs6393_s16/nist-SP800-145.pdf 
Murah, M.Zamri. (2012). Teaching and learning cloud computing. UKM Teaching and Learning Congress 2011. Procedia - Social and Behavioral Sciences 59 (2012) 157 - 163, https://ac.els-cdn.com/S1877042812037081/1s2.0-S1877042812037081-main.pdf?_tid=4594e88b-ce7d-45a0-bd6c953e6d36e8a5\&acdnat=1527508489_b32108eaa2adbf424141a079b70f319a

Obukowicz, M. etal. (2009).AssisstivetechnologyforOrganization, AssessingStudents' NeedsforAssistive Technology. 2009.http://www.wati.org/wp-content/uploads/2017/10/Ch9-Organization.pdf

Reed, P. JillGierach.AssessingStudents' NeedsforAssistive Technology(ASNAT) Process. Assessing Students' Needs for Assistive Technology. 2017. http://www.wati.org/wp-content/uploads/2017/10/Ch1-ATAssessment.pdf

Watkins, A. (2012). Teacher Education for Inclusion, Profile of inclusive teachers. European Agency for Development in Special Needs Education, ISBN (Electronic): 978-87-7110-337-3, 2012.

Wilson, N. (2017). A guide to information and services, Definitions and categories of assistive technologies. 2017. http://www.assistivetechnologyguide.co.uk/ guides/definitions-and-categories-of-at/ 